It indicates that the detailed mechanism of protein synthesis may be diverse in the various genera of bacteria.

$\begin{array}{ll}\text { Institute of Applied Microbiology, } & \text { N. Tamaguch } \\ \text { Nanaka }\end{array}$

The University of Tokyo, Bunkyo-Ku.

'Tanaka, N., Yamaguchi, H., und Umezawa, H., J. Antibiotics, Tokyo, 14, A, 60 (1961)

2 Yamaguchi, H., J. Antibiotics, Tokyo, 14, A, 313 (1961).

Y amaguchi, H., J. Antibiotics, Tokyo, 16, A, 92 (1963).

4 Yamaguchi, H., J. Antibiotics, Tokyo, 16, A, 97 (1963).

- Vazquez, D., Biochim. Biophys. Acta, 61, 849 (1962).

'Lacks, S., and Gros, F., J. Mol. Biol., 1, 301 (1959).

"Hopkins, J. W., Proc. U.S. Nat. Acad. Sci., 45, 1461 (1959).

${ }^{8}$ Brock, T. D., Bact. Rev., 25, 32 (1961).

'Nathans, D., and Lipmann, F., Proc. U.S. Nat. Acad. Sci., 47, 497 (1961).

${ }^{10}$ Tarmolinsky, M. B., and de la Haba, G. L., Proc. U.S. Nat. Acad. Sci., 45, 1721 (1959).

"Takeda, Y., Hayashi, S., Nakagawa, H., and Suzuki, F., J. Biochem., Tokyo, 48, 169 (1960).

1: von Ehrenstein, G., and Lipmann, F., Proc. U.S. Nat. Acad. Sci., 47, 941 (1961).

1: Morris, A., Favelukes, S., Arlinghaus, R., and Schweet, R., Biochem. Biophys. Res. Comm., ri, 326 (1962).

${ }^{14}$ Rabinovitz, M., and Fisher, J. M., J. Biol. Chem, 237, 477 (1962).

${ }^{15}$ Rendi, R., and Ochoa, S., Science, 113, 1369 (1961).

16 Rendi, R., and Ochoa, S., J. Biol. Chem., 237, 3711 (1962).

${ }^{17}$ Sirkevitz, 1., J. Biol. Chem., 195, 549 (1952).

\section{Conversion of Tritiated-18-hydroxy- corticosterone to Aldosterone by Slices of Human Cortico-adrenal Gland and Adrenal Tumour}

Progesterone (pregn-4-ene-3,20-dione), corticosterone (11 3,21 -dihydroxypregn-4-ene-3,20-dione) and deoxycorticosterone (21-hydroxypregn-4-ene-3,20-dione) have been shown to be precursors of aldosterone $e^{1-5}$. Aldosterone (11 $\beta, 21$-dihydroxypregn-4-ene-3,20-dione-18-al) is produced in the glomerulosa zona of the adrenal cortex ${ }^{6-8}$. It could be assumed that the biogenesis of aldosterone was preceded by hydroxylation of corticosterone in $\mathrm{C}_{18}$. Nicolis and Uliek $^{9}$ obtained a slight yield of aldosterone (0.2 per cent) by incubation of tritiated-18-hydroxy-corticosterone (i1 $, 18,21$-trihydroxypregn-4-ene-3,20-dione) with bull-frog adrenal tissue and beef zona glomerulosa tissue. Stachenko and Giroud ${ }^{10}$ considered that the cyclic $18 \rightarrow 20$ hemiketal form of 18-hydroxy-corticosterone ${ }^{11}$ was responsible for this lack of conversion of 18-hydroxy-corticosterone to aldosterone.

This work demonstrates that human cortico-adrenal tissue is capable of converting tritiated-18-hydroxy-corticosterone (kindly supplied by Dr. S. Ulick) to tritiatedaldosterone with a considerable yield. The adrenal cortex and adrenal tumour of a patient with primary hyperaldosteronism $^{12}$ were removed. The tumour was separated from the adrenal gland tissue and slices taken from two parts. $0 \cdot 6$-g slices of adrenal tumour and $0.7 \mathrm{~g}$ of corticoadrenal tissue were incubated with $10 \mathrm{ml}$. of Krebsphosphate solution $(p \mathrm{H} 7 \cdot 4)^{13}, 5 \mathrm{mg}$ of diphosphopyridine nucleotide (DPN) and $50 \mathrm{mg}$ of sodium fumarate. 60,000 c.p.m. of tritiated-18-hydroxy-corticosterone were added to the first incubation and 50,000 to the second. After incubation at $37^{\circ} \mathrm{C}$ for $3 \mathrm{~h}$, the slices were ground in a Waring blender and the proteins precipitated with $25 \mathrm{ml}$. of 96 per cent ethanol. The supernatant was evaporated to dryness, the residue dissolved in $25 \mathrm{ml}$. of 90 per cent ethanol, left at $-10^{\circ} \mathrm{C}$ for three days and centrifuged. The supernatant was evaporated to dryness, the residue dissolved in $25 \mathrm{ml}$. of 80 per cent methanol, left for three days at $-10^{\circ} \mathrm{C}$ and centrifuged. The supernatant was evaporated to dryness, the residue dissolved in $20 \mathrm{ml}$. of water and extracted three times with 1 vol. of dichloromethane. The dry dichloromethane extract was chromatographed successively in the chloroform/formamide, toluene-ethyl-acetate/methanol-water (9-1/5-5) and iso- octane-ter-butyl alcohol-water (10-5-9) systems. After elution of the aldosterone zone in the third chromatogram, the radioactivity was measured in an automatic liquid scintillator (Tri-carb model $314 E X$, Packard Automatic Instrument Co.). Part of this elution was acetylated and the product obtained had the same mobility as synthetic aldosterone diacetate in the iso-octane-toluene/methanolwater system $(1-4 / 5-5)$.

Quantitative evaluation of 1,2-tritiated-aldosterone was determined by a method dorived from that of Kliman and Peterson ${ }^{14}$.

Table 1 shows the percentage of transfer of tritiated-18. hydroxy-corticosterone to aldosterone after incubation.

\begin{tabular}{|c|c|c|c|}
\hline & $\begin{array}{c}{ }^{3} \mathrm{H}-18 \text {-hydroxy- } \\
\text { corticosterone } \\
\text { (c.p.m. incubated) }\end{array}$ & $\begin{array}{c}{ }^{3} \mathrm{H} \text {-aldosterone } \\
\text { produced } \\
\text { (c.p.m.) }\end{array}$ & $\begin{array}{l}\text { Yicld } \\
(\%)\end{array}$ \\
\hline Cortico-adrenal tissue & 50,000 & 5,300 & $10 \cdot 60$ \\
\hline mour tissue & 60,000 & 2,300 & 3.85 \\
\hline
\end{tabular}

Human cortico-adrenal tissue, as well as adrenal tumour of Conn's syndrome, is eapable of converting tritiated-18-hydroxy-corticosterone to tritiated-aldosterone with yield of $10 \cdot 60$ and 4.33 per cent, respectively, for the quantities incubated. Thus, the biogenesis of aldo. sterone appears to occur in the following sequence: cholesterol $\rightarrow$ progesterone $\rightarrow$ deoxy-corticosterone $\rightarrow$ corticosterone $\rightarrow$ 18-hydroxy-corticosterone $\rightarrow$ aldosterone.

Laboratoire de Chimie Biologique, JoRge R. PASQualint

Faculté de Médecine, Paris VI.

${ }^{1}$ Kant, F. W., Neher, R., and Wettstein, A., Experientia, 11, 446 (1956).

${ }^{2}$ Wettstein, A., Kant, F. W., and Neher, R., Ciba Found. Coll. Endocrinol., 8,170 (1955).

Ayres, P. J., Hechter, O., Saba, N., Simpson, S. A., and Tait, J. F., Biochem. J., 65, 22, P (1956).

4 Stachenko, J., and Giroud, C. J. P., Endocrinol., 64, 730 (1959). Ayres, P. J., Eichhorn, J., Hechter, O., Saba, N., Tait, J. F., and Tait,
S. A. S., Acta Endocrinol., 33, 27 (1960). -Ayres, P. J., Gould, R. P., Simpson, S. A., and Tait, J. F., Biochem. J.,
68, 19, P'(1956). 7 Giroud, C. J. P., Stachenko, J. J., and Venning, E. H., Proc. Soc. Exp.
Biol. and Med., 92, 154 (1956).

8 Travis, R., and Farrell, G. L., Fed. Proc., 17, 324 (1958).

${ }^{9}$ Nicolis, G., and Ulick, S., Intern. Cong. Hormonal Steroids (Milan), 218 (Excerpta Medica Found., 1962).

${ }^{10}$ Stachenko, J., and Giroud, C. J. P., Intern. Symp. Adrenal Cortex and Adrenal Cortical Hormones (Ghent), 77 (1962).

${ }^{11}$ Schmidlin, J., and Wettstein, A., Helv. Chim. Acta, 43, 973 (1960).

12 Conn, J. W., J. Lab. Clin. Med., 45, 3 (1955).

${ }^{13}$ Krebs, H. A., and Henseleit, K., Hoppe-Seyler's Z. physiol. Chem., 210, 33 (1932).

${ }^{14}$ Kliman, B., and Peterson, R. E., J. Biol. Chem., 235, 1639 (1960).

\section{Inhibition of Phenylalanine Incorporation by Polyuridylic Acid}

Adpition of polyuridylic acid (poly U) to cell-free: systems prepared from a number of tissues results in enhaneed incorporation of phenylalanine into polypeptide material ${ }^{1-4}$. Arnstein et al. ${ }^{2}$ noted that, when poly $\mathrm{U}$ was added to a reticulocyte ribosome system, the incorporation of other amino-acids was not inhibited and they concluded that natural messenger RNA ( $m$-RNA) was not displaced from the ribosomes by the poly $U$. They questioned whether the poly $U$ effect on phenylalanine incorporation had any physiological significance. Weinstein et al. ${ }^{5}$ later showed that incorporation of some amino-acids was inhibited when poly $U$ was added to reticulocyte ribosomes. The present report concerns an instance when poly $\mathrm{U}$. added to rat liver polysomes prepared in the absence of magnesium, actually inhibited phenylalanine incorporation. It is argued that this anomalous occurrence, paradoxically, strengthens the concept that poly $\mathrm{U}$ stimulation of phenylalanine incorporation is a reflexion of physiological events.

Rat liver was homogenized in $0 \cdot 25 \mathrm{M}$ sucrose in the cold and centrifuged at $15,000 \mathrm{~g}$ for $10 \mathrm{~min}$. Sodium 